DOI 10.37882/2223-2982.2020.12.22

\title{
НЕОЛОГИЗМЫ КАК ДОСТОЯНИЕ ИНДИВИДА (НА МАТЕРИАЛЕ АНГЛОЯЗЫЧНЫХ НЕОЛОГИЗМОВ В СФЕРЕ ПСИХОЛОГИИ)
}

\section{NEOLOGISMS AS THE INDIVIDUAL'S PROPERTY (BASED \\ ON ENGLISH-LANGUAGE NEOLOGISMS IN THE FIELD OF PSYCHOLOGY) \\ O. Litvyak \\ L. Suprun}

Summary: The article is devoted to the problem of the emergence of new English-language neologisms in the field of psychology. Based on the psycholinguistic theory, as well as on the basis of a number of electronic dictionaries, the analysis is carried out, where new lexical neoplasms related to psychological science are considered. The theoretical part of the article includes the study of modern word-formation trends in the English language, concepts and principles, the role of neologisms and their use in the oral and written speech of an individual. Psycholinguistic experiment was used as the main empirical research method, and the method of interlanguage translation was used as its methodology. The experiment was conducted on the material of neologisms from the field of psychology. The empirical part of the article also provides examples of neologisms that describe the state and appearance of an individual, as well as psychological components of the individual.

Keywords: individual, neologism, neology, language creativity, psychological aspect, psychology, borrowing, word formation, lexicon.
Литвяк Олеся Валерьевна

к.ф.н., дочент, ГБОУВО РК «Крымский инженернопедагогический университет имени Февзи Якубова»

Ole.litviak@yandex.ru

Супрун Лилия Сергеевна

ГБОУВО РК «Крымский инженерно-педагогический университет имени Февзи Якубова»

liliy.suprun@mail.ru

Аннотация: Статья посвящена проблеме возникновения новейших англоязычных неологизмов в сфере психологии. С опорой на психолингвистическую теорию, а также на основе ряда электронных словарей проведен анализ, где рассматриваются новые лексические новообразования, связанные с психологической наукой. Теоретическая часть статьи включает исследование современных словообразовательных тенденций в английском языке, понятий и принципов, роль неологизмов и их употребления в устной и письменной речи индивида. В качестве основного эмпирического метода исследования использовался психолингвистический эксперимент, в качестве его методики - метод межъязыкового перевода. Эксперимент проводился на материале неологизмов из сферы психологии. В эмпирической части статьи также приведены примеры неологизмов, описывающих состояние и внешний вид индивида, психологические компоненты личности.

Ключевые слова: индивид, неологизм, неология, языковое творчество, психологический аспект, психология, заимствование, словообразование, лексикон.

\section{Постановка проблемы}

$\Pi$ роблема, связанная с возникновением и функционированием новых слов, всегда была актуальной в лингвистике. Каждый язык мира овладевает новыми словами, которые описывают те или иные явления современной действительности. Некоторые новые слова не уживаются в языке и постепенно исчезают в речи, а какие-то укореняются и остаются надолго. Такие слова носят название «неологизмы» [4]. В языкознании неологизм означает «новое слово или выражение, а также новое значение старого слова» [8, с. 406]. И.В. Арнольд определяет неологизмы как устойчивые выражения, заимствованные из другого языка и воспринимаемые носителями данного языка как нечто новое [7; 1, с. 232]. По мнению Е.В. Сенько [10], «неология» - «не сложившаяся, а пока лишь формирующаяся наука в области языкознания. Это считается нормальным и естественным процессом, так как любая наука не сразу становится готовой, а проходит сложный и долгий пусть становления [13]. В данной статье мы рассмотрим становление новой науки «неологии», какую роль она играет в психолингвистике, понимание неологизмов как один из видов языкового творчества и возникновение англоязычных неологизмов в сфере психологии. Также, нами будет затронута тема о влиянии неологизмов на совершенствование речи индивида.

\section{Анализ митературы}

Основой для написания данной научной статьи послужили работы отечественных исследователей в области психолингвистики таких, как Е.В. Сенько, К.А. Власова, Т.Ю. Мкртчян, С.А. Чугунова, Ю.А. Мельник, Е.А. Штехман, С.И. Тогоева, Л.В. Шалина, Л.С. Выготский, В.Г. Гак, В.В. Виноградов.

Цель работы - теоретически обосновать роль неологизмов в устной и письменной речи индивида, возникновение англоязычных неологизмов в сфере психологии.

\section{Изложение основного материала}

Как отмечает С.А. Чугунова, в XX веке произошёл так 
называемый «неологический бум», который привёл к возникновению новой науки под названием лингвистическая неология - наука о новациях в языке [12]. В период общественных перемен произошло интенсивное пополнение словарного состава языка. Исследователи русского языка, такие как М.А. Кронгауз, М.Н. Эпштейн, Г.Ч. Гусейнов, Л.О. Чернейко, отмечают подъём словообразовательной активности и в нашем современном коммуникативном пространстве [5]. Изучение новых слов на материале конкретных языков развивается по различным направлениям: с точки зрения их статуса в системе языка и их типологии [11]. Ю. Мкртчян выяснила, что обогащение словарного состава происходит тремя способами: синтаксическим (словообразование), семантическим (изменения значения слова, его переосмысление) и при помощи заимствования [7; 8, с. 74]. С.А. Чугунова отмечает, что неологизмы являются видами языкового творчества. Язык непрерывно реагирует на изменения во всех сферах человеческого общества, благодаря природной пластичности языка и его способности к развитию и адаптации, создаётся новый лексикон какого-либо языка. Н. Хомский рассматривает ментальный лексикон не как некий словарь, а как совокупность генеративных принципов, обусловливающих изменения и обновления в языке. Он же доказывает, что причина творческой потенции языка так же не ясна в наше время, как и три века назад Декарту, хотя очевидно, что язык отражает творческий характер человеческого мышления [12]. Ю.А. Мельник, Е.А. Штехман отмечают, что один из важнейших признаков неологизмов - это их принятие и закрепление в общем употреблении (письменной и устной речи), то есть вхождение в лексическую систему языка, в разряд общеупотребительной выделяет признаки [5]. Исследуя психолингвистические подходы, Л.В. Шалина приводит в своей статье «К вопросу о сущности неологизма в современной лингвистике» основные признаки неологизмов, выделенные отечественными учеными. Р.А. Будагов, А.В. Калинин, Е.В. Розен, Н.М. Шанский выделяют в качестве основного признака неологизма его абсолютную новизну. Другие исследователи в области «неологии», такие как, В.В. Виноградов, Б.Н. Головин, Е.В. Розен, М.Н. Золотарева, считают главным критерием временной, так как согласно их мнению неологизмами являются слова, возникшие на памяти использующего их поколения. По современным статистическим данным, в развитых языках появляются десятки тысяч неологизмов, что свидетельствует о так называемом «неологическом взрыве» - «neology blow uр». Постепенно неологизмы осваиваются и становятся общеупотребительными в лексиконе носителей языка, а затем перестают быть неологизмами. Как отмечает К.А. Власова, слово находится в состоянии неологизма очень непродолжительное время. Как только слово начинает активно употребляться, оно теряет признак новизны, то есть постепенно входит в лексическую систему языка в качестве общеупотребительного [4].
К вопросу о том, как неологизмы могут влиять на формирование и совершенствование индивида. Каждый человек, представитель вида Homo sapiens и носитель индивидуально-своеобразных черт является индивидом. Когда представитель Homo sapiens вписывается в социум, он становится личностью. Благодаря особой совершенной формы общения присущей только человеку, то есть речи, индивид в процессе коммуникации может обмениваться своими мыслями и чувствами, а также взаимодействовать друг на друга [9]. Таким образом, с помощью коммуникации, индивид совершенствуется.

Общение с помощью речи осуществляется посредством языка. Язык, как система фонетических, лексических и грамматических средств общения, на протяжении времени изменяется, обогащается, развивается, совершенствуется. Как мы отмечали ранее, самым значимым свидетельством подвижности характера языка, как живой и динамической системы, является его способность изменять свой словарный состав. С.И. Тогоева выдвигает позицию о том, что новые слова появляются благодаря специфике когнитивной деятельности индивида, индивидуальным особенностям и творческому подходу в речи человека [11]. Исследуя проблемы неологии с психолингвистических позиций, С.И. Тогоева сделала заключение о том, что в процессе коммуникативно-познавательной деятельности человека развивается внутренний индивидуальный лексикон. Специфика восприятия и усвоения новых слов у каждого индивида разная. Л.В. Шалина подчеркивает, что каждый исследователь рассматривает новые слова со своих позиций, выдвигает на передний план те критерии, которые сообразуются с его целевой установкой [13]. В оксфордском словаре по психологии отмечается, что создание новых слов (неологизмов) или использование уже существующих слов или терминов новыми способами часто считается творческим действием индивида [2]. В.Г. Гак обращает внимание на то, что большая часть неологизмов образуется с помощью внутренних ресурсов индивида. Внутренние средства помогают переосмыслить новые образованные слова и создать с помощью них словосочетания. В.В. Виноградов считает, что «неологизмы» рождаются в связи с потребностью общества коммуницировать (названия новых предметов, фактов, понятий, явлений), а не для удовлетворения экспрессивно- эмоциональных надобностей индивида. Автор полагает, что основная функция неологизмов - номинативная. Номинативная функция служит непосредственно для ориентации человека в пространстве и времени, а также идет рука об руку с познавательной функцией и участвует в процессе познания мира. Рассматривая процессы изучения новых лексических единиц, советский психолог и лингвист, Л.С. Выготский, отмечал, что в языке слово воплощает в себе единство коммуникации и мышления. На основании вышесказанного можно сделать вывод, что возникновение языковых новообразований необходимо 
рассматривать не только как процесс номинации, но и одновременно как процесс познания и коммуникации [3].

В сфере психологии, основой изучения которой являются закономерности возникновения, развития и функционирования психики и психической деятельности человека и групп людей, тоже имеет место быть новым словам, заимствованным из других иностранных языков, а также созданным и преобразованным благодаря мыслительным процессам индивида и его творческому речевому подходу. Однако, прежде следует отметить, что психология - одна из самых перспективных и актуальных наук, так как все более возрастает роль и значение людей, их психики и сознания. Е.А. Мигунова [6] отмечает, что в прежние десятилетия психология была преимущественно мировоззренческой дисциплиной. В наше время, роль психологии существенно изменилась, так как она приобрела практическую значимость и стала актуальна в системе образования, в промышленности, государственном управлении, медицине, культуре, спорте и так далее. [6]. Таким образом, в сфере психологии появление новых слов (неологизмов) могут значительно скрасить лексикон практического психолога. Также следует отметить, что пациенты обращаются за помощью для облегчения своего эмоционального состояния; прояснения внутренних, психологических проблем за помощью в принятии своей болезни; с вопросами о том, как справляться с эмоциями, агрессией; как общаться в своей семьей, с друзьями, на работе; они обращаются за помощью в нахождении внутренних ресурсов преодоления болезни; с запросами, связанными с профилактикой рецидивов, дальнейшей жизнью в условиях болезни и прочее [6]. На основе вышесказанного можно сделать вывод о том, что, используя новые словообразования, пациенты могут легко и понятно описать свою проблему, поделиться своими чувствами, состоянием с психологом.

Рассмотрим некоторые примеры неологизмов из сферы психологии, описывающих психологические компоненты и состояния личности:

-Неологизмы, связанные с чувствами, эмоциями и состояниями:

Humblebrag - хвастливое высказывание, которое автор пытается скрыть за маской самоиронии, шутя в жанре: - «Да я вообще кто? Да никто!», т.е. скромное хвастовство;

Me time - личное время, посвященное самому себе, а не потраченное на решение проблем других людей и работу, время для снижения стресса и восстановления энергии;

Perfectionist paralysis- состояние человека, препятствующее началу работы из- за неуверенности в достижении успеха;

Curb shame - смущение, которые испытывает человек, послушно ожидающий зеленого светофора, в то время, как остальные переходы переходят на красный свет из-за отсутствия движения машин;

Dreamathon- состояние, в котором человек много раз подряд выключает будильник и успевает в промежутках между звонками будильника увидеть новый сон;

Bromance- крепкая мужская дружба;

Digital hangover - чувство стыда, которое накрывает на следующее утро после вечеринки, если знакомые или друзья уже успели выложить в социальные сети фотографии или видео с компроматом;

Threenager (three + teenager) - ребенок, переживающий так называемый

«кризис трех лет», который по своим проявлениям напоминает подростковый бунт;

Refrigerator rights («Рефрижераторное право») - синоним очень дружеских доверительных отношений, что может означать право залезть в холодильник без спроса;

Bedgazm - удовольствие, которое человек испытывает, когда в конце изнурительного рабочего дня ему удается добраться до дивана, при этом человек как будто выпадает из реальности и лежит без движений около 20 минут;

Aha moment - момент, когда вы резко вспомнили чтолибо, в который до вас что-то «дошло»;

Attention spam - состояние, при котором невозможно сосредоточиться, и поэтому человек совершает нелепые ошибки в простых вещах из-за переизбытка ненужных мыслей в голове;

Headdesk - высшая степень отчаяния и разочарования из-за чьей-то глупости; это чувство сильнее «facepalm» примерно в три раза;

Book hangover (рус. «Книжное похмелье») - чувство, что окружающий мир несовершенен и сюрреалистичен, которое появляется сразу осле окончания прочтения книги и мешающее человеку вернуться в реальность;

Name ambush (рус. «Именная засада») - неловкое чувство, возникающее при встрече с вроде бы знакомым человеком, но при этом не помните, как его зовут;

Presenteeism - чувство вины, возникающее у работника, который отлучился из офиса, даже если по причине болезни;

Cinematherapy - так называемая «кино-терапия», похожа на «шоппинг- терапию», но в этом случае от стресса избавляются в кинотеатрах.

\section{Выво $\Delta$}

Таким образом, проблема к изучению неологизмов в настоящее время выросла ещё больше, зародилась новая область лингвистики под названием «неология», которая занимается определением способов выявления новых слов и значений, анализирует факторы их появления, изучает процессы и модели их создания, разрабатывает принципы их лексической обработки. Существуют разные взгляды на понятие «неологизм» и их природу. Обобщая вышесказанное можно сделать вывод, неоло- 
гизм - есть новая единица (устойчивое словосочетание или слово), новая по форме и по значению (или только по значению или только по форме), созданная по слово или фразообразовательным моделям данного языка или заимствованная из другого языка и воспринимаемая носителями языка в качестве новой в течение некоторого промежутка времени. В современном английском языке возникновение неологизмов представляет собой активное пополнение словарного состава и обогащения языка в целом. Индивид за счет создания, а затем и использования словарных новообразований, развивает свой когнитивный и коммуникативно-познавательный процесс и совершенствуется благодаря своему творческому подходу в речи. Лексический состав английского языка в сфере психологии также пополнился за счёт новообразований, что позволяет значительно скрасить речь психологов и пациентов.

\section{ЛИТЕРАТУРА}

1. Арнольд И.В. Лексикология современного английского языка. М.: Высшая школа, 1973. 302 с.

2. Библиография: Оксфордский толковый словарь по психологии / Под ред. А. Ребера. - М.: Вече, АСТ, 2002.

3. Бухорова М.Х. Номинативная функция языка и её функционирование в речи // Журнал Вопросы науки и образования, - 2020. - С. 60-64 [Электронный ресурс]. - Режим доступа: URL: https://cyberleninka.ru/article/n/nominativnaya-funktsiya-yazyka-i-ee-funktsionirovanie-v-rechi (дата обращения: 06.11.2020)

4. Власова К.А. К вопросу о неологизмах / К.А. Власова, Д.А. Вьюшкина. - Текст: непосредственный // Актуальные вопросы филологических наук: материалы IV Междунар. науч. конф. (г. Казань, октябрь 2016 г.). — Казань: Бук, 2016. — С. 29-31.

5. Мельник Ю.А., Штехман Е.А. К вопросу о статусе неологизма в современной лингвистике // Журнал Современные проблемы науки и образования. - 2015. - №2 (часть 1) [Электронный ресурс]. - Режим доступа: URL: https://www.science-education.ru/ru/article/view?id=21100 (дата обращения: 06.11.2020)

6. Мигунова Е.А. Актуальность психологической науки в современном мире // Журнал Актуальные проблемы гуманитарных и естественных наук, - 2015. - [Электронный ресурс]. - Режим доступа: URL: https://cyberleninka.ru/article/n/aktualnost-psihologicheskoy-nauki-v-sovremennom-mire (дата обращения: 06.11.2020)

7. Мкртчян Т.Ю. К вопросу о способах образования новейших неологизмов в английском языке // Журнал Филологические науки. Вопросы теории и практики.-2017.- №9 (75): в 2-х ч. Ч. 1. С. 140-142

8. Ожегов С.И. Словарь русского языка: 70000 слов / Под ред. Н.Ю. Шведовой. — М.: Рус. Яз., 1990. — 921 с.

9. Разлогов К.Э. Индивид - личность - творческая личность: мифы и реальность // Журнал Ярославский педагогический вестник, - 2015 - №1 - Том 1. C. 61-65 [Электронный ресурс]. - Режим доступа: URL: https://cyberleninka.ru/article/n/individ-lichnost-tvorcheskaya-lichnost-mify-i-realnost (дата 0бращения: 06.11.2020)

10. Сенько Е.В. Теоретические основы неологии. Владикавказ. 2001. С. 16

11. Тогоева С.И. Психолингвистические проблемы неологии: дис. ... д-ра фил. наук. Теория языка, Тверь, 2000. - 251 с. [Электронный ресурс]. - Режим доступа: URL:https://www.dissercat.com/content/psikholingvisticheskie-problemy-neologii

12. Чугунова С.А. Неологизимы как достояние индивида (на материале англоязычных неологизмов из сферы моды) // Вопросы психолонгвистики. - 2019 [Электронный ресурс]. - Режим доступа: URL:https://cyberleninka.ru/article/n/neologizimy-kak-dostoyanie-individa-na-materiale-angloyazychnyhneologizmov-iz-sfery-mody (дата обращения: 06.11.2020)

13. Шалина Л.В. К вопросу о сущности неологизма в современной лингвистике // Журнал Известия Пензенского государственного педагогического университета им. В.Г. Белинского. - 2007. - С.73 -77 [Электронный ресурс]. - Режим доступа: URL: https://cyberleninka.ru/article/n/k-voprosu-0-suschnostineologizma-v-sovremennoy-lingvistike (дата обращения: 06.11.2020) 